\title{
PSYCHOLOGICAL STUDY OF THE CREATIVITY OF A MODERN MANAGER
}

\author{
Poghosyan S.H. (Public Administration Academy of RA, Yerevan, Armenia) \\ sona.poghosyan@paara.am \\ 乙tipluјugर्uाध uर्u. 31.07.2021 \\ 9pmpunuर्यiध uर्u. 14.08.2021

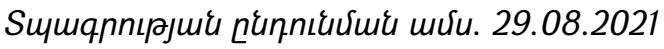

\begin{abstract}
Nowadays the training of the managers requires improvement, which implies training a creative manager, who can work in uncertain and emergency situations. People who express their creativity have special personality traits. However, the correlation of the creativity and personality traits in management has not been sufficiently studied. It is also necessary to study the creativity methods based on the correlation between creativity and personality traits. If we consider creativity as the core system-creating quality for all traits, we can assume which traits of a person will be displayed in case of the expression of creativity. The purpose of this article is to study the creativity of a specialist as a system creating quality. Combined with the personality traits and the application of creativity methods it ensures the proposal of unique and new ideas. For this purpose we did research. We used the tests by F. Williams for creativity assessment and for discovering the individual qualities of a creative person, Cattell's 16 Personality Factors Test, Ryff's Psychological Wellbeing Scale. Thus, for the creative solution of the problem, personal traits are needed, which will help to express the standards of creativity. However, appropriate methods, motivation and psychological security are needed for the effectiveness of the creative process in professional activities.
\end{abstract}

Keywords: creativity, personality, manager, psychological well-being, research, unique.

DOI: https://doi.org/10.46991/SBMP/2021.4.2.283

Today, the issue of the training of specialists in management requires improvement, which implies the training of the specialists who can meet modern challenges. Creative people are encouraged to be involved in the modern management, moreover they are demanded as they can work in uncertain, difficult, emergency situations. It is obvious that the creative professionals ensure the progress of the management. However, along with its urgency and necessity, the following question can often be asked: what is creativity for, why is it necessary for a person to show creativity, if his/her work does not require problem solving or problem solving with new means and methods? Especially in the case when it is quite 
difficult to manage creative employees, as it is mentioned in A. Maslow's and L. Echeverria's works [7, 9].

We can conclude that the creativity of a person is vital, up-to-date, but difficult to manage. Creativity is the useful and effective answer to the changes of evolution. Social and technological changes are based on creative people and processes. [5] We agree with the researchers who mention that creativity is the main resource of humanity [1]. According to A. Maslow, the interest in creativity goes beyond the borders of psychology and psychiatry. The ability to create is becoming an essential issue of national and international politics [7]. It means that creativity, as an important quality, is needed to survive, live and improve oneself in the modern world. It should become the imperative of modern education.

Based on this if we teach and develop the creativity of a person, we will have specialists, who are determined, independent and innovative.

Creativity is a process of idea generation, problem solving and the actual idea or solution [3, p.6]. In addition, to show creativity one needs individual qualities. There are a lot of approaches to the problem of the individual features of a creative person (R. Cattell, F. Barron, R. Sternberg, T. Lyubart, T. Barysheva, Yu. Zhigalov, A. Olakh, T. Amabile, M. Collins, M. Mihaly Csikszentmihalyi, V. Druzhinin). Our researches demonstrate the co-dependency of individual qualities and creativity [12]. We should take into account that such correlations have not yet been sufficiently studied, especially among managers. The individual qualities of managers in management are explored by A. Maslow, M. Nelke, O. Makarenko, N. Lazarev, R. Yagolkovski, A. Morozov, and L. Markova.

Summing up theoretical approaches, we can define the features typical for creative people. We think that these features are essential in management. These features are the ability to notice the problem, ingenuity, flexibility, originality, tolerance for uncertainty, leadership, social courage, the ability to take risks, perseverance, self-regulation, imagination, striving for perfection, the ability to think independently, freedom, receptivity, and aesthetic sense.

Having such qualities, a manager can raise problems on his/her own, solve them in a unique way, take a risk, and show initiative in the managerial activity. Creative people are open, flexible and ready to take risks [4, p. 6.] And finally, it is the inherent flexibility of creative people that gives them the ability to overcome the achievements, opportunities, technologies and changes that are part of our daily life [5]. Creative decisions are always risky and unpredictable. Therefore, by developing a person's creativity, we can definitely have people who are independent, innovative and initiating.

It should be noted that the correlation of the creativity and personality features in management has not been sufficiently studied. Moreover, there is a need to study which creativity methods a person uses based on the correlation between creativity 
and personality features, as the application of the creativity methods is related to the personal qualities.

However, if we put creativity at the core of all qualities as a system-building quality, then by determining the qualities of creative people, we can assume what qualities a person will display in the presence of creativity. The way of the development of creativity is: problem - creative process - problem solving creativity obstacles - creative result. In this process personal qualities such as sensitivity to the problems and perception of novelty, concentration on the problem, independence, tolerance for uncertainty, divergent thinking ability, flexibility, and originality are also important. So, in order to solve the problem creatively we need personal qualities, which will give us the opportunity to reveal the elements of creativity.

Taking into account the fact that creative people are sensitive to problems, we can assume that the manifestation of creativity in professional activities begins with the discovery and speaking about the problem. The number of problems is huge. While solving them we seek new ways and create novelty. The creative approach in the problem-solving process involves the use of a number of methods: divergence, convergence, transformation, change of strategies, thinking modes, Metchetta method. By using, these methods new knowledge, new strategies, new solutions are created, which are of public importance. But we need to combine these methods with the creative thinking indicators.. This can ensure the manifestation of the person's flexibility and originality. This gives the opportunity to get rid of the repetitions and ready examples during the problem-solving process and propose new approaches and concepts.

In this model we give a special role to psychological security, as for the manifestation of the person's creativity a psychologically secure environment is needed. It means that creativity becomes active when there is a proper environment (V. Druzhinin) [6]. On the other hand the application of the creative approaches and results gives the opportunity to create psychological security. In fact, it turns out to be a closed chain. In such an environment, it is possible to give freedom to everyone, which will allow a person to take risks, to propose and generate new ideas and approaches. There is an opinion in the professional literature that in case of the low level of psychological security prerequisites for personal security breaches may be identified, including situational depressions, despondency and lack of creativity [10]. Creative potential is hindered when one does not feel safe and tries to protect oneself. That is, psychological security is a fundamental necessity for the creative people. It is especially emphasized for modern management, where creativity and innovation are mentioned among the primary values as part of the corporate culture. In order to show a creative approach and to come up with a new idea, a person must feel that his potential can be accepted, that someone will actually 
listen to him [2]. As creative people have tolerance for uncertainty and the ability to take risks [11] they can easily overcome uncertain situations and come up with new solutions, thus providing a secure environment. However, it should be noted that according to the results of our studies high level self-assessment of creativity is inversely proportional to the psychological well - being. The rationale for this is presented in the research results. The model we have developed is: person-solution of the problem-motivation-potential discovery - self-confidence - the ability to see the problem in a new way- overcoming uncertain situations - psychological security - new ideas.

We conducted a study among 30 executive and mid-level managers of different organizations They are students of the chair of management at the Public Administration Academy of RA. The aim of the study was to identify the relationship between the level of creativity of managers, personal qualities of creativity, personal qualities and "psychological well-being". Research was done using the methods of diagnostics by $F$. Williams for creativity assessment and for discovering the individual qualities of a creative person, Cattell's 16 Personality Factors Test, Ryff's Psychological Wellbeing Scale.

The results of the research showed that managers have high level of creativity (According to the test, 131 is considered a high score of creativity). (Figure 1).

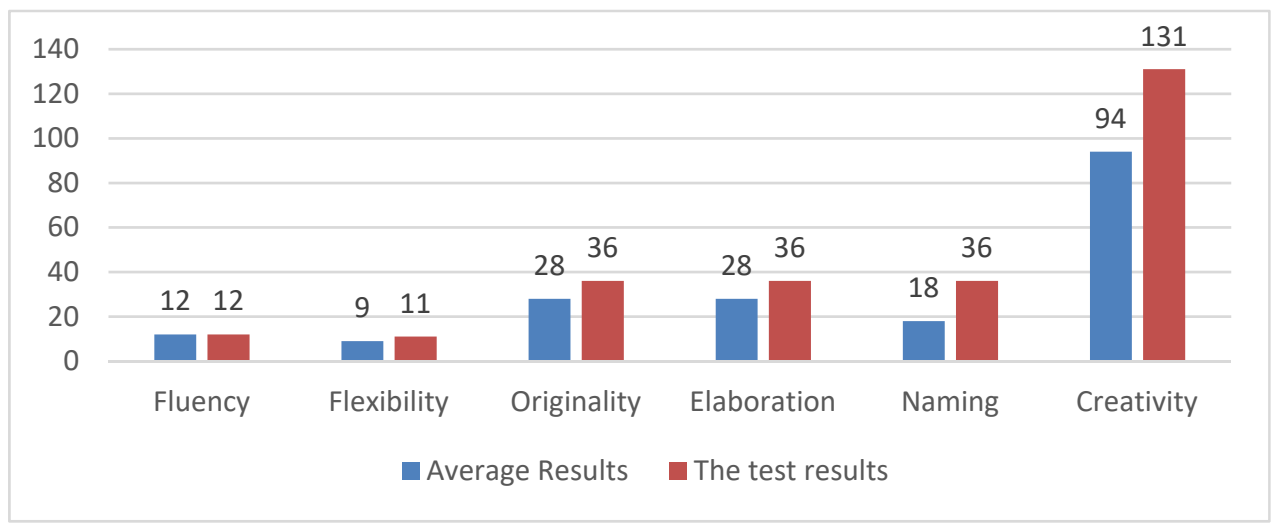

Figure 1. Creativity Level of Managers and indicators of Creativity: Average Results $(n=30)$

The indicators of Fluency, Flexibility, Originality, and Elaboration are high. The Naming indicator is low, which means that managers can come up with a large number of unique ideas that belong to different classes, improve them, but do not always use them creatively. We can compare these indicators of creativity with the data of another research group conducted among 30 senior managers of different organizations. Their creativity index is considered above average, 85 but differs 
from the data of the research group presented by us $(t=3.5$, according to the Critical Values of the Student's t Distribution, the difference is significant: 0.001).

Referring to the results of the psychological well-being survey, we can see that the level of psychological well-being is high among managers. (According to the test, 354 or more is considered a high score of psychological well-being). (Figure 2)

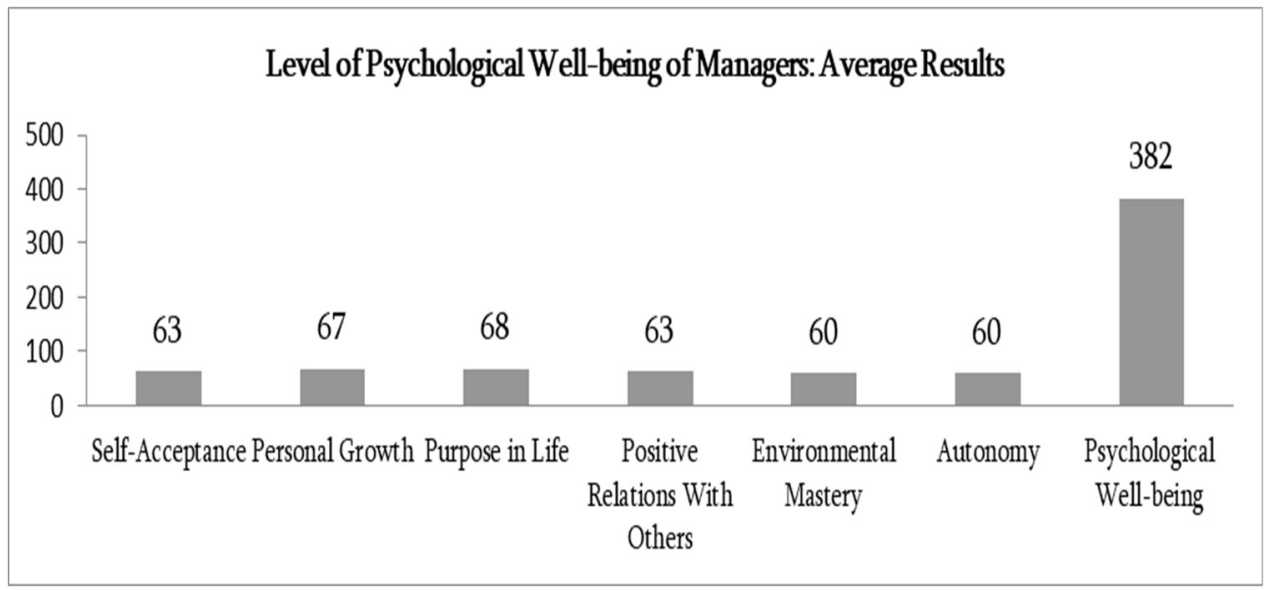
$(n=30)$

The criteria of Personal growth and Purpose in life are high among managers. This means that they have goals and direction in their lives, feeling of continuous personal growth and they are open for new experiences.

From personal qualities, managers have high level Rule-consciousness $(M=11)$, Openness to change $(M=9)$ and Perfectionism $(M=9)$, which means that they are guided by the sense of duty and responsibility, follow the established norms, tend to experiment, are receptive to new things, control the expression of emotions and feelings. The results of the research argue that managers are receptive to the new experience, according to the results of the tests by Cattell and Ryff.

According to F. Williams's, the test personal qualities of creativity are Curiosity, Risk-taking ability, Imagination and Complexity.[8] From personal qualities of creativity, managers have high level of Curiosity $(M=17)$, Risk-taking ability $(M=16)$, Imagination $(M=15)$. Self-assessment of creativity is above average $(M=62$, the test norms is 100). They show interest in puzzle-problems. They are curious and try to discover the hidden meaning of things. They look for alternatives, solve difficult problems. The correlation analysis $(n=30)$ between the results of indicators of creative thinking, personal qualities of creativity, personal qualities and psychological well-being showed that there are significant connections between them. 
Both negative and positive connections among the indicators of creativity, personal qualities of creativity and personal qualities are remarkable. There is a correlation between Flexibility and Reasoning $(r=-0.312, P<0,05)$, Fluency and Warmth $(r=0.447, P<0,01)$, Originality and Dominance $(r=0.333, P<0,05)$, Openness to change $(r=0.446, P<0,01)$, Liveliness $(r=0.426, P<0,01$, ), Emotional stability $(r=0.343, P<0,05)$, Elaboration and Social boldness $(r=0.431, P<0,01)$, Naming and Rule-consciousness $(r=0.460 \mathrm{P}<0,01$, ), Openness to change $(r=0.400$, $\mathrm{P}<0,01)$, Risk-taking and Reasoning $(r=0.413, P<0,01)$, Curiosity and Dominance $(r=-0.323, \quad P<0,05)$, Imagination and Rule-consciousness $(r=0.353)$, Selfassessment of creativity and Social boldness $(r=-0.330, P<0,05)$.

These connections show that the more managers come up with the unique ideas in large quantities, the easier they communicate, are receptive to the new things, control the expression of emotions and feelings. They find it difficult to put forward ideas belonging to different categories in case of high intellectual potential (the negative connection between the Reasoning and Flexibility), but the ability to take risks is high. They can constructively accept criticism and defend their own ideas (Risk-taking and Reasoning). All this once again reveals the controversial issue of intellect and creativity. The more they develop ideas, the more they are bold. The most interesting thing is that when they have courage, they underestimate their creativity. When they have creative speech, they are guided by a sense of duty and responsibility, are receptive to the new thing, and tend to experiment.

There is no correlation between the indicators of creativity and psychological well-being. However there are negative connections between personal qualities of creativity and psychological well-being. There are negative connections between Risk-taking and Purpose in life $(r=-0.376, P<0,01)$, Environmental mastery ( $r=-$ $0.322, P<0,05)$, Complexity and Psychological well-being $(r=-0.411, P<0,01)$, Selfacceptance $(r=-0.464, P<0,01)$, Positive relations with others $(r=-0.452, P<0,01)$, Imagination and Psychological well-being $(r=-0.420)$, Self-acceptance $(r=-0.471, P<$ $0,001$,$) , Purpose in life (r=-0.477, P<0,001)$, Self-assessment of creativity and Psychological well-being $(r=-0.418, P<0,01)$, Self-acceptance $(r=-0.502, P<$ $0,001)$, Purpose in life $(r=-0.444, P<0,01)$, Environmental mastery $(r=-0.376, P<$ $0,01)$, except Autonomy $(r=0.324, P<0,05)$.

These connections testify that the more the managers are constructive in accepting criticism, the more they predict the likelihood of failure. The more they try to make assumptions, act in unstructured situations, look for alternatives, solve difficult problems, build mental images, trust intuition, the more they find it difficult to manage daily activities, have few goals and intentions, lack sense of direction, are dissatisfied with themselves, have very few intimate relationships, are more isolated in interpersonal relationships, are not inclined to compromise to maintain interpersonal relationships, are independent and autonomous, self-regulate their 
behaviour, are able to resist the compulsion of others to act in a certain way, evaluate themselves according to their personal criteria. It turns out that the higher the self-assessment of managers' creativity, the lower the psychological well-being.

The results of the research before the content analysis seemed contradictory. However this kind of description is typical for creative people.

Thus, we can conclude that the level of creativity among managers is high. They are characterized by psychological well-being, rule-consciousness, social boldness and perfectionism, curiosity, risk-taking ability and imagination. The hypothesis is confirmed: when we consider creativity as the core system building quality for all traits, we can assume which traits of a person will be displayed in case of the expression of creativity.

\section{References}

1. Batey M., Furnham A. Creativity, intelligence and personality, a critical review of the scattered literature, Genetic Social and General Psychology Monographs, 132(4), 2006, pp. 355-429, p. 355.

2. Fortune $\mathbf{S}$. Why psychological safety is the key to creativity and innovation in the workplace, The Oxford Group, 2018, available: https://www.oxfordgroup.com/insights/why-psychological-safety-key-creativity-and-innovationworkplace, 28.07.2021

3. Carmeli A., Reiter-Palmon R, Ziv E. Inclusive Leadership and Employee Involvement in Creative Tasks in the Workplace: The Mediating Role of Psychological Safety, University of Nebraska, Psychology Faculty Publications, 2010, p. 6 (Amabile, 1983; Sternberg, 1988; Weisberg, 1988).

4. Carmeli A., Reiter-Palmon R, Ziv E. Inclusive Leadership and Employee Involvement in Creative Tasks in the Workplace: The Mediating Role of Psychological Safety, University of Nebraska, Psychology Faculty Publications, 2010, p. 6 (Barron \& Harrington, 1981; Dewett, 2006; Feist, 1998; Sternberg \& Lubart, 1991).

5. Runco M.A. Creativity, Annual Review of Psychology, Vol. 55, 2004, pp. 657-687.

https://doi.org/10.1146/annurev.psych.55.090902.141502 .

6. Дружинин В. Н. Психология общих способностей. 3- издание, СПб., Питер, 2007, 368 с.

7. Маслоу А. Дальные пределы человеческой психики, СПб, Питер, 2017, 448c., c. 136.

8. Туник Е. Е. Модифицированные креативные тесты Вильямса. СПб., Речь, 2003, 96 с.

9. Эчеверия Л. Креативная революция: лидерство, которое поощряет творчество и создает инновации, Москва, Э., 2015, 304с. 
10. Эсмурзиева М. Проектирование психологической безопасности креативных проявлений личности подростков в условиях инновационной образовательной среды, Пятигорский государственный университет, 2011, доступ:

https://pgu.ru/upload/iblock/15c/uch_2011_xi_00015.pdf, 28.07.2021.

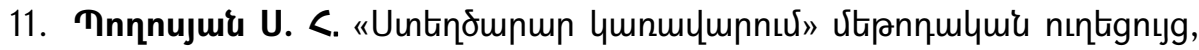
tplumiu, htin. hpuin., 2018, 80 5:

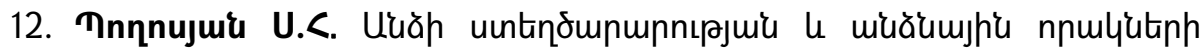

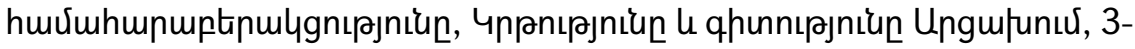
4, 2018, 5, 26-3.

\section{ПСИХОЛОГИЧЕСКОЕ ИССЛЕДОВАНИЕ КРЕАТИВНОСТИ СОВРЕМЕННЫХ МЕНЕДЖЕРОВ}

Погосян С. Г. (АГУ РА, Ереван, Армения)

В управленческой деятельности вопрос подготовки кадров требует совершенствования, что предполагает подготовку таких специалистов, которые смогут устоять перед современными вызовами. В современной управленческой деятельности поощряются, более того востребованы креативные личности, которые умеют работать в неопределенных, сложных, экстремальных ситуациях. Для проявления креативности нужны личностные качества. Недостаточно исследовано взаимосвязь креативности и личностных качеств личности, более того есть необходимость специального исследования того, при каком взаимодействии креативности и личностных качеств личность какой метод креативности использует, так как использование креативных методов связано с личностными качествами. Однако если в основе всех качеств поставим креативность, как системообразующее качество, то выделяя качества креативных личностей можем предположить, какие качества личность проявит при наличии креативности. Целью является исследование креативности специалиста как системообразующее качество, которое в сочетании с личностными качествами и использованием креативными методами, способствует предложению оригинальных, новых идей. Для исследования использовали метод тестирования. Использовали тесты на креативность и личностные качества Вильямса, 16-фракторный тест личности Кеттеля, личностный опросник Риффа о психологическом благополучии. Таким образом, для творческого решения задачи необходимы личные качества, дающие возможность выражать критерии креативности. Однако необходимы соответствующие методы и мотивация, психологическая безопасность, использование которых может обеспечить эфффективность творческого процесса в профессиональной деятельности. 
Ключевые слова: креативность, личность, менеджер, психологическое благополучие, исследование, оригинальный.

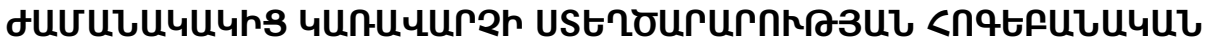

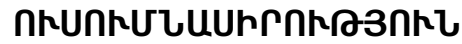

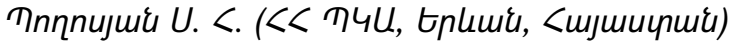

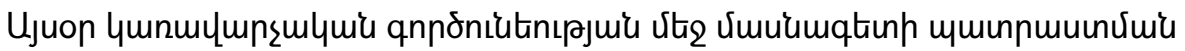

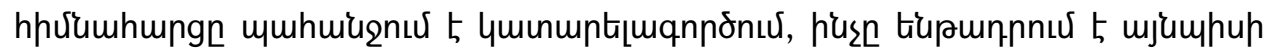

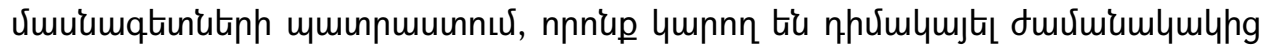

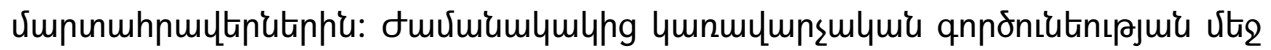

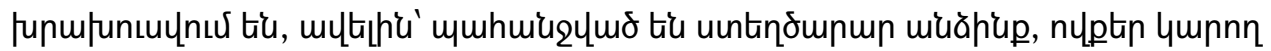

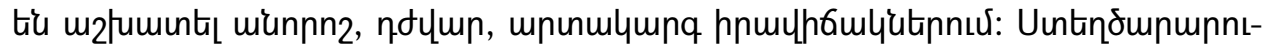

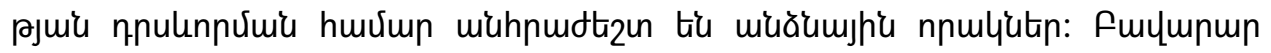

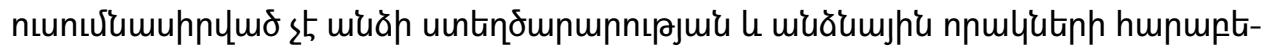

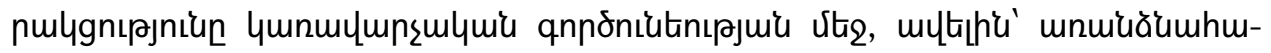

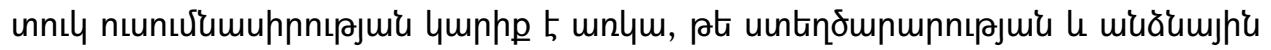

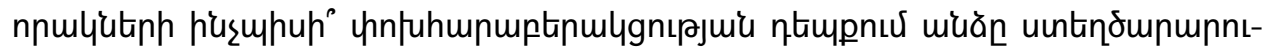

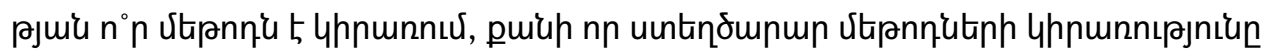

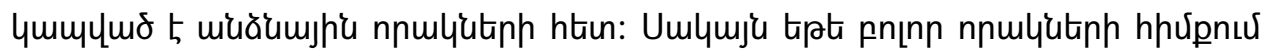

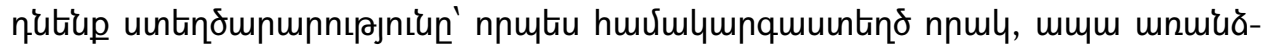

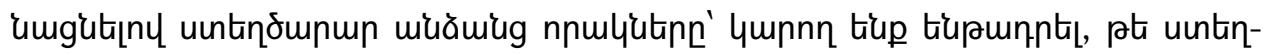

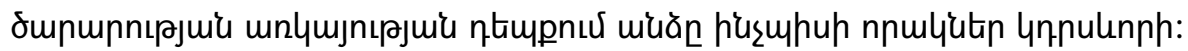

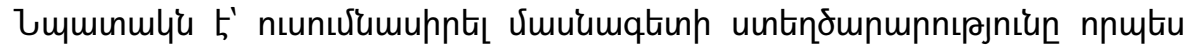

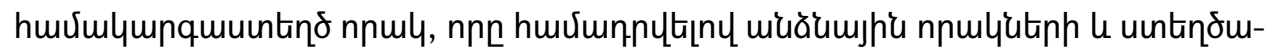

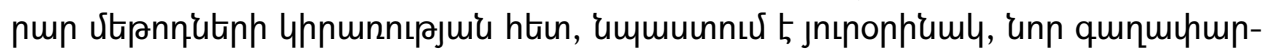

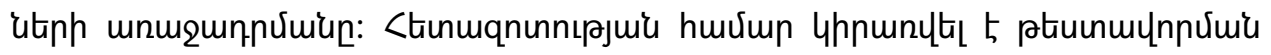

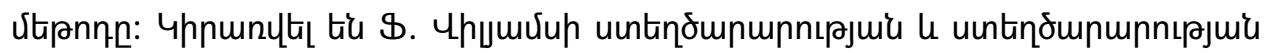

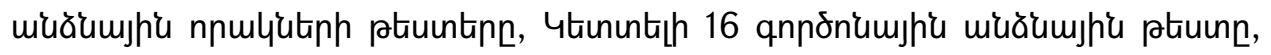

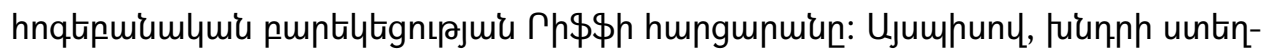

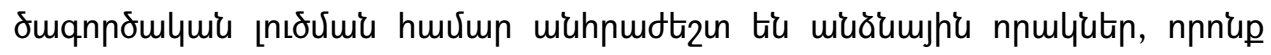

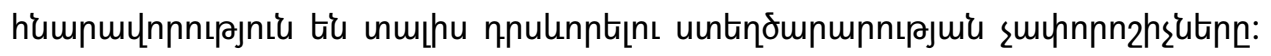

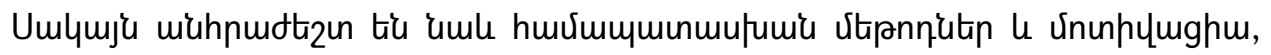

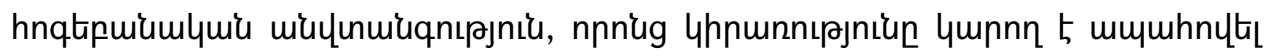

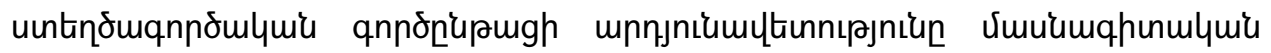

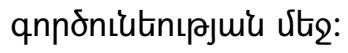

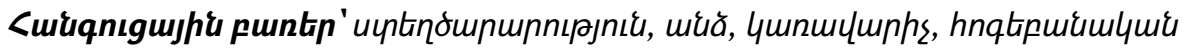

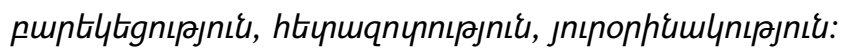

